\title{
Meme Kanseri Hastalarında hTERT Gen Ekspresyonunun Klinikopatolojik Önemi
}

\author{
Ebubekir DİRICAN ${ }^{1}$, Burak KANKAYA ${ }^{2}$, Zeynep TATAR ${ }^{3}$
}

ÖZ

Amaç: Bu çalışma, meme kanserinde insan telomeraz ters transkriptaz (hTERT) genin mRNA ekspresyonunun klinik önemini incelemeyi ve klinikopatolojik rolünü araştırmayı amaçlamıştır. hTERT geni hücre proliferasyonu, apoptoz ve hücre invazyonu gibi olaylarda rol almaktadır. Yüksek hTERT mRNA ekspresyonunun meme kanseri, mide, akciğer, glioblastoma, baş ve boyun gibi solid tümörlerde kötü prognoz ile ilişkili olduğu bildirilmektedir.

Gereç ve Yöntemler: 59 meme kanser ve sağlıklı kan örneklerinin RNA izolasyonları gerçekleştirildi. hTERT geni mRNA ekspresyonu Gerçek Zamanlı Polimeraz Zincir Reaksiyonu (RT-PZR) yöntemi ile analiz edildi. mRNA ekspresyon sonuçları $2^{-\Delta \Delta c t}$ metoduyla kanserli ve sağlıklı örneklerde değerlendirildi. Klinik veriler toplandı ve bu verilerin hTERT gen ekspresyonu ile ilişsisi istatiksel olarak değerlendirildi.

Bulgular: Meme kanser hastalarında hTERT geni mRNA ekspresyonu sağlıklı örneklere kıyasla anlamlı derecede yüksekti $(\mathrm{p}=0,0211)$. Düşük hTERT geni ekspresyonu östrojen reseptör (ÖR) $(+)$ ve insan epidermal büyüme faktör reseptörü 2 (HER 2) (+) olan hastalarda anlamlı derecede ilişkiliydi (sırasıyla $\mathrm{p}=0,0464 ; \mathrm{p}=0,0080$ ). hTERT geni ekspresyonu histolojik derece (grade) 3 hastalarda derece 2'ye kıyasla yüksek anlamlı bulundu ( $\mathrm{p}=0,0389)$. Bununla birlikte hTERT ekspresyonun bazal benzeri histolojik tipte luminal A ve luminal B'ye kıyasla anlamlı derecede yüksek olduğu gösterildi (sırasıly $\mathrm{p}=0,0160 ; \mathrm{p}=0,0008$ ).

Sonuç: Çalışmamızın bulguları, meme kanser hastalarında hTERT gen ekspresyonunun sağlıklı örneklere göre anlamlı olarak daha yüksek olduğunu gösterdi. Anormal hTERT gen ekspresyonu kanserojenez veya teşhiste önemli bir rol oynayabilir.

Anahtar Kelimeler: Meme kanseri; hTERT; ÖR; PZR; bazal benzeri; luminal.

\section{Clinicopathological Significance of hTERT gene expression in Breast Cancer Patients}

\begin{abstract}
Aim: This study aimed to examine the clinical significance of the mRNA expression of the human telomerase reverse transcriptase (hTERT) gene in breast cancer (BCa) and to investigate its clinicopathological role. The hTERT gene is involved in events such as cell proliferation, apoptosis and cell invasion. It has been reported that high hTERT mRNA expression is associated with poor prognosis in solid tumors such as BCa, stomach, lung, glioblastoma, head and neck.

Material and Methods: RNA isolations of $59 \mathrm{BCa}$ and healthy blood samples were performed. hTERT gene mRNA expression was analyzed by Real-Time-Polymerase Chain Reaction (RT-PCR) method. mRNA expression results were evaluated in cancer and healthy samples by the $2^{-\Delta \Delta \mathrm{ct}}$ method. Clinical data were collected and the relationship of these data with hTERT gene expression was evaluated statistically.

Results: hTERT gene mRNA expression in BCa patients was significantly higher than in healty samples $(\mathrm{p}=0,0211)$. Low hTERT gene expression was significantly associated with estrogen receptor (ER) $(+)$ and human epidermal growth factor receptor 2 (HER 2) (+) patients $(\mathrm{p}=0.0464 ; \mathrm{p}=0.0080$, respectively). hTERT gene expression was found to be higher in histological grade 3 patients compared to grade $2(\mathrm{p}=0.0389)$. Moreover, hTERT expression was shown to be significantly higher in basal-like histological type compared to luminal A and luminal B ( $\mathrm{p}=0.0160 ; \mathrm{p}=0.0008$, respectively).

Conclusion: The findings of our study showed that hTERT gene expression was significantly higher in BCa patients than in healthy samples. Abnormal hTERT gene expression may play an important role in carcinogenesis or diagnosis.
\end{abstract}

Keywords: Breast cancer; hTERT; ER; PCR; Basal like; luminal

\footnotetext{
1 Bayburt Üniversitesi, Sağlık Hizmetleri Meslek Yüksekokulu, Eczane Hizmetleri Programı, Bayburt, TÜRKIYE

2 İstanbul Aydın Üniversitesi, Tıp Fakültesi, Genel Cerrahi Anabilim Dalı, İstanbul, TÜRKIYE
}

3 İstanbul Atlas Üniversitesi,Tıbbi Patoloji Anabilim Dalı, İstanbul, TÜRKIYE

Sorumlu Yazar / Corresponding Author: Ebubekir DiRiCAN, e-mail: ebubekirdirican@bayburt.edu.tr 


\section{GiRiş}

Meme kanseri dünya genelinde kadınlar arasında en yaygın görülen kanser türüdür (1). Telomeraz ekspresyonunun insan tümör hücreleri için gerekli olduğu ve insan telomeraz ters transkriptaz (hTERT) genin ekspresyon profilinin telomer boyu ve telomeraz enzim aktivitesi için önemli olabileceği belirtilmiştir $(2,3)$. hTERT geni, telomeraz kompleksinin katalitik alt ünitesinde yer alıyor olup, insan tümörlerinin \%85'inde yüksek eksprese olduğu ve bunun zayıf prognozla ilişkili olduğundan bahsedilmiştir $(4,5)$. hTERT genin, normal somatik hücrelerde az yada hiç eksprese olmadiğ bildirilmiştir (6). hTERT geni ekspresyon durumunun, telomer boyunun korunması ile ilişkili olabileceği ve kanser hücrelerinin sınırsız proliferasyon yetenekleri olduğu için önemli olabileceği düşünülmektedir. Kanser hücrelerinde telomerazın aşırı ekspresyon durumunun bazı mutasyonlardan, kromozomal dengesizliklerden veya MYC (MYC Proto-Oncogene, BHLH Transcription Factor) genin ekspresyonunun artmasıyla ilişkili olabilir. hTERT genin hücre proliferasyonu, apoptozla dirençte ve invazyonu etkileme gibi fonksiyonları vardır (7). Yüksek hTERT ekspresyonunun, mide, akciğer, servikal, baş ve boyun, meme ve yumurtalık kanseri ve glioblastoma gibi solid (katı) tümörlerde kötü prognoz ile ilişkili olduğu rapor edilmiştir $(8,9)$. hTERT'in aşırı ekspresyonu, daha kısa medyan tekrarlama süresi ve ölümle ilişkilidir ve bu da onu umut verici bir ilaç hedefi haline getirmektedir (10).

Bizde bütün bu bilgiler ışığında, bu çalışmamızda meme kanser hastalarının kan örneklerinde hTERT geni mRNA ekspresyonunu analiz etmeyi ve hastalarımızın klinikopatolojik verileriyle olan ilişkisini ortaya çıkarmayı amaçladık. Elde ettiğimiz verilerin hTERT mRNA ekspresyonu ile telomeraz aktivitesi arasında bir bağlantı olabileceğini ve gelecekteki meme kanser çalışmalarına 1şık tutacağını ümit ediyoruz.

\section{GEREC VE YÖNTEMLER}

\section{Örneklerin toplanması}

Bu çalışmaya İstanbul Aydın Ünivesitesi Hastanesi Genel Cerrahi Anabilim Dalı'na başvuran 59 adet neoadjuvan kemoterapi almamış meme kanser tanısı konmuş hastalar ile meme kanser tanısı almamış 59 sağlıklı gönüllü tam kan örnekleri dahil edilmiştir. Örneklerin toplanması için gerekli etik kurul izinleri için Atatürk Üniversitesi Tıp Fakültesi Etik kurulundan onay alınmıştır (Etik no:2021/197B.30.2.ATA.0.01.00). Bir uzman patolog tarafından kanser hastalarının patolojik verileri değerlendirildi. Tüm bireylerin kan örnekleri hemogram tüpte alındı ve izolasyon aşamasına kadar $\left(-80^{\circ} \mathrm{C}\right)^{`} \mathrm{de}$ saklandi.

\section{RNA izolasyonu}

Tüm örneklerimizin RNA izolasyonları için Epitech pure RNA izolasyon kiti (Türkiye) kullanıldı ve Bayburt Üniversitesi, SHMYO, Tıbbi Biyoloji ve Genetik Laboratuvarı'nda başarıyla gerçekleştirildi. Örneklerin izolasyonu tamamlandiktan sonra Take3 Plate (BioTek, Winooski Vermont, USA) Nanodrop cihazında 260/280 nm dalga boyunda, izolasyonu gerçekleştirilen örneklerin RNA kaliteleri ve konsantrasyonları analiz edildi ve RTPCR işlemleri gerçekleştirilinceye kadar $-20^{\circ} \mathrm{C}^{\circ} \mathrm{de}$ muhafaza edildi.

\section{cDNA sentez reaksiyonu}

RNA örnekleri kolay kırılma özelliğine sahip olduğu için gen ekspresyon deneyleri yapılıncaya kadar kararlı bir yap1 olan cDNA formuna dönüşümleri gerçekleştirildi. cDNA sentezi için iScript ${ }^{\mathrm{TM}}$ cDNA sentez kiti (Bio-Rad) kullanıld1. cDNA sentez reaksiyonu için $4 \mu \mathrm{l} 5 \mathrm{x}$ iScript reaction miks, $1 \mu \mathrm{l}$ iScript reverse transcriptase, $8 \mu \mathrm{l}$ RNA ve üzeri su ile $20 \mu$ l'ye tamalanarak kitin önerdiği sıcaklıklarda thermalcycler (1sı döngüsü) cihazında reaksiyon gerçekleştirildi.

\section{hTERT geni mRNA ekspresyon analizi}

hTERT mRNA ekspresyon analizi için Atatürk Üniversitesi, DAYTAM Merkez Araştırma Laboratuvarı'ndaki Bio-Rad CFX-96 RT-PCR cihazı kullanıld1. $10 \mu \mathrm{l}$ SYBR Green master miks (SsoAdvanced Universal SYBR Green Master Supemix), $5 \mu 1$ cDNA, 1 'er $\mu 1$ ileri (forward) ve geri (reverse) primerler ve üzeri su ile $20 \mu \mathrm{l}$ tamamlanarak reaksiyon hTERT için master miksinde üretici firmanın önerdiği sıcaklık ayarlarında reaksiyon gerçekleştirildi. Housekeeping Beta-actin ve hTERT geni için aşağıdaki primerler kullandı.

Beta-actin geni için;

Forward Primer:

5-TCCTCCTACCGAGCGCATGTAGTACTC-3

Reverse Primer:

5-CTGCAGCTTGCTGATCGTTCACATCTG-3

hTERT geni için;

Forward (ileri) Primer:

5-GCCGATCGATGTGAACGGCATGGACTACG-3

Reverse (geri) Primer:

5-GCTCGCGATAGCGGTTGAGCACGCTGAA-3

İstatistiksel Analiz

İstatiksel analizler için GraphPad Prism Version 7.04 and SPSS software 16 programları kullanıldı. Gen ekspresyon analizleri için önce $2^{-\Delta \Delta C t}$ metodu kullanılarak hTERT genin ekspresyonu beta actinle normalize edilerek hesapland1. Daha sonra gruplara göre gen ekpresyon sonuçlarının normal dağılıp dağılmadığını D'Agostino \& Pearson ve Shapiro-Wilk normalite testleriyle değerlendirdik ve buna göre parametrik/non parametrik test seçimleri yapılarak gruplar arasındaki farkların istatiksel analizleri gerçekleştirildi. hTERT geni ekspresyonun HER2 (+)/(-), ER (+)/ (-) durumlar1 göre, kanserli ve sağlıklı örneklerdeki dağılımlarının analizi için Mann Whitney U testi kullanıldı. hTERT geni ekspresyonun histolojik grade 2 ve grade 3 durumuna göre dağılımlarının analizi için Student's t-testi kullanıldı. hTERT geni ekspresyonun meme kanser moleküler alt tiplerine göre dağılımlarının analizi için One Way Anova kullanıldı. $\mathrm{p}<0.05$ olduğunda istatiksel olarak anlamlı kabul edildi.

\section{BULGULAR}

\section{Meme kanser hastalarının klinik verilerinin dağılımları}

Meme kanser örneklerimizin yaş ortalaması 40,5 $\pm 17,68$ olarak belirlendi. Örneklerimizin klinikopatolojik verilerinin dağılımlarına baktığımızda örneklerin \%44,07'si luminal B moleküler tipte, \%66,10'u invazif duktal karsinom, \%35,60's1 tümör stage (safha) 2, $\% 44,07$ 'si histolojik grade 3, \%38,98'i nod-1 durumuna sahip olduklarını gösterdik. Bununla birlikte, hormon reseptör durumlarına göre hastalarımızın dağılımlarına 
baktığımızda hastaların \%59,32'si östrojen reseptör durumu (ER) pozitif, \%62,71'i progesteron reseptör (PR) ve \%61,01'i hormon reseptör (HER2) negatif olduklarını gösterdik. Son olarak hastaların Ki-67 durumlarına göre dağılımlarına baktığımızda \%59,32'si 14'ten büyük olduklarını gösterdik (Tablo 1).

\begin{tabular}{|c|c|}
\hline $\begin{array}{l}\text { Klinikopatolojik } \\
\text { parametreler }\end{array}$ & Toplam hasta sayisı \\
\hline \multicolumn{2}{|l|}{ Moleküler tip } \\
\hline Luminal A & 12 \\
\hline Luminal B & 26 \\
\hline Bazal & 8 \\
\hline HER2 & 2 \\
\hline Tanımlanamadı & 11 \\
\hline \multicolumn{2}{|l|}{ Hitolojik tip } \\
\hline Invazif duktal & 39 \\
\hline Invazif miks & 9 \\
\hline Invazif lobular & 1 \\
\hline Bazal benzeri & - \\
\hline *Diğer & 2 \\
\hline Tanımlanamadl & 8 \\
\hline \multicolumn{2}{|l|}{ Tümör safhası } \\
\hline$T 1$ & 21 \\
\hline$T 2$ & 20 \\
\hline$T 3$ & 6 \\
\hline$T 4$ & - \\
\hline Tanımlanamadl & 12 \\
\hline \multicolumn{2}{|l|}{ Histolojik grade } \\
\hline$G 2$ & 21 \\
\hline G3 & 26 \\
\hline G5 & 2 \\
\hline Tanımlanamadl & 10 \\
\hline \multicolumn{2}{|l|}{ Nod durumu } \\
\hline NO & 18 \\
\hline N1 & 23 \\
\hline$N 2$ & 5 \\
\hline N3 & 1 \\
\hline Tanımlanamadl & 12 \\
\hline \multicolumn{2}{|l|}{ Yaş } \\
\hline$<50$ & 25 \\
\hline$\geq 50$ & 27 \\
\hline Tanımlanamadl & 7 \\
\hline \multicolumn{2}{|c|}{ Hormon reseptör durumu } \\
\hline$\ddot{O} R(+)$ & 35 \\
\hline$E R(-)$ & 13 \\
\hline Tanımlanamadl & 11 \\
\hline$P R(+)$ & 37 \\
\hline$P R(-)$ & 11 \\
\hline Tanımlanamad $\iota$ & 11 \\
\hline HER2 (+) & 12 \\
\hline HER2 (-) & 36 \\
\hline Tanımlanamad $\iota$ & 11 \\
\hline \multicolumn{2}{|l|}{ Ki-67 durumu } \\
\hline$<14$ & 12 \\
\hline$\geq 14$ & 35 \\
\hline Tanımlanamadı & 12 \\
\hline $\begin{array}{l}\text { Pleomorfik } \quad \text { lobular } \\
\text { karsinoma; } \\
\text { PR:Arogesteron } \\
\text { s:Prowth factor }\end{array}$ & $\begin{array}{l}\text { karsinoma, metaplastik } \\
\text { ÖR: Östrojen reseptörü; } \\
\text { HER2: Human epidermal }\end{array}$ \\
\hline
\end{tabular}

Sağlıklı ve kanserli örneklerdeki hTERT geni ekspresyonun dağılımı

Sağlıklı ve kanserli örneklerin hTERT gen ekspresyon analiz sonuçlarına baktığımızda, hTERT genin tümörlü örneklerde sağlıklı örneklere kıyasla anlamlı düzeyde yüksek eksprese olduğunu gösterdik ( $p=0,0211)$ (Grafik $1)$.

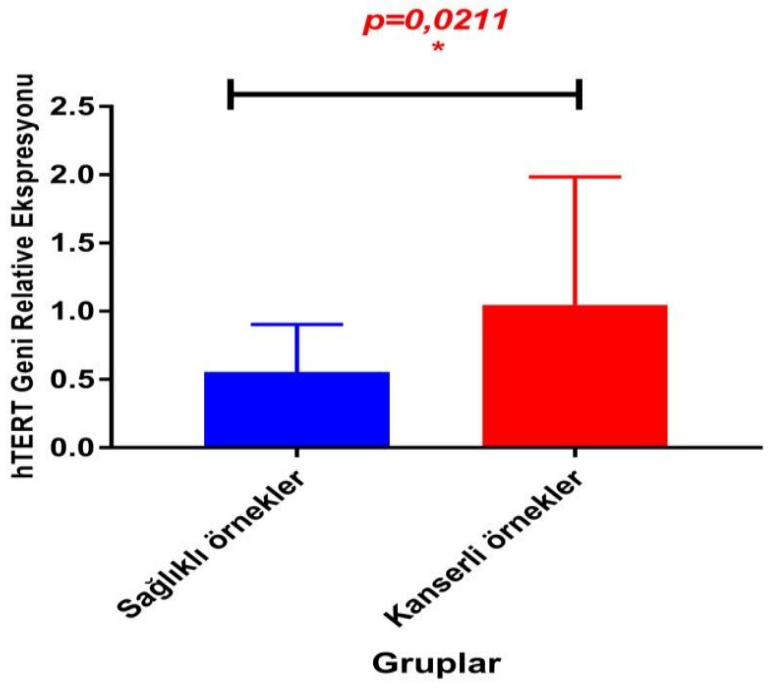

Grafik 1. Sağlıklı ve meme kanser örneklerinde hTERT geni ekspresyonun dağılımı $(p=0,0211)$

\section{hTERT geni ekspresyonun klinikopatolojik verilere} göre dağılımı

ER(+) ve HER2(+) olan meme kanser örneklerinde hTERT geni ekspresyonunu istatiksel olarak anlamlı düzeyde düşük olduğu gösterildi (sırasıyla $\mathrm{p}=0,0464$; $\mathrm{p}=0,0080)$ (Grafik 2).

Histolojik derece-3'e sahip örneklerde, hTERT genin ekspresyon seviyesinin histolojik derece-2'ye sahip olan örneklere kıyasla yüksek olduğu belirlendi $(\mathrm{p}=0,0389)$ (Grafik 3). Bununla birlikte bazal benzeri moleküler tipte hTERT geni ekspresyon seviyesinin luminal A ve luminal B'ye kıyasla anlamlı ve yüksek olduğu gösterildi (sırasiyla $\mathrm{p}=0,0160 ; \mathrm{p}=0,0008$ ) (Grafik 4).
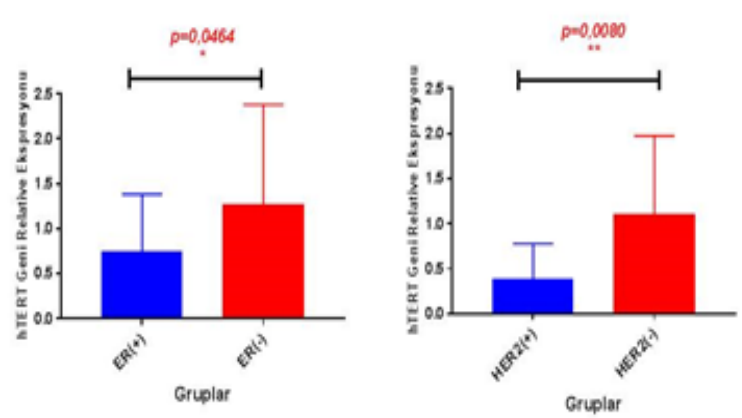

A 
Grafik 2. A) ER (+) ve B) HER2 (+) meme kanser örneklerinde hTERT geni ekspresyonun dağılımı (sirasiyla $\mathrm{p}=0,0464 ; \mathrm{p}=0,0080$ )

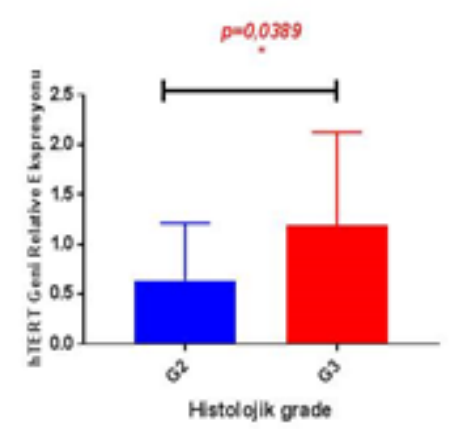

Grafik 3. Histolojik grade 2 ve grade 3 meme kanser örneklerinde hTERT geni ekspresyonun dağılımı $(\mathrm{p}=0,0389)$

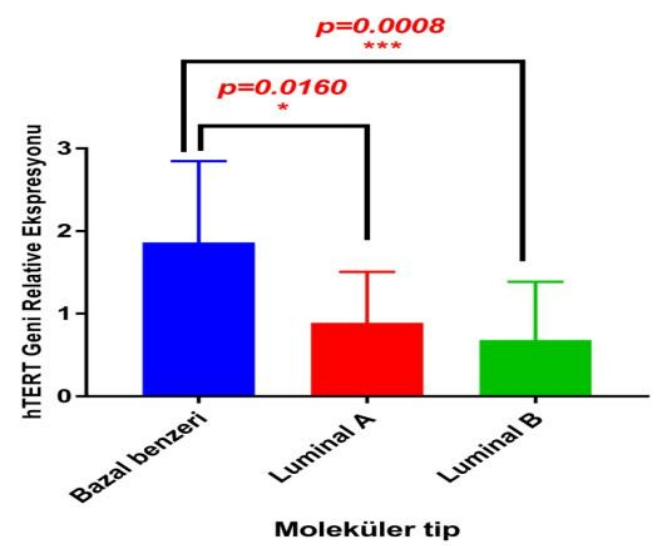

Grafik 4. Meme kanser örneklerinde moleküler tiplere göre hTERT geni ekspresyonun dağılımı (sırasıyla $\mathrm{p}=0,0160 ; \mathrm{p}=0,0008$ )

\section{TARTIŞMA}

Meme kanseri kompleks ve heterojen bir hastalı olup kadınlar arasında kanserden ölümlerin önemli bir sebebidir (11). Biz meme kanserinde çeşitli çevresel ve genetik faktörlerin kanserin patofizyolojisini etkileyebildiğini ve kanserin ilerlemesinden sorumlu olabileceklerini tahmin edebiliyoruz. Bizde bu çalışmada meme kanserinde önemli olabilecek olan hTERT geninin ekspresyonunu sağlıklı ve meme kanserli örneklerde analiz ettik. Ayrica hTERT genin ekspresyonunu meme kanser hastalarının klinikopatotolojik özelliklerine göre ekpresyon dağılımlarını inceledik.

TERT, telomeraz enziminin katalitik bir alt birimidir ve insanlarda hTERT olarak kisaltılır. Telomeraz, tümör oluşumundaki ana rolü nedeniyle kanser hücrelerinde küresel bir terapötik hedef olarak bilinir (12). Kanser hücreleri, telomerazı kodlayan normalde sessiz olan hTERT'i aktive ederek veya düzenleyerek proliferatif ölümsüzlüğe ulaşırlar (13). Kanser hücrelerinde, normal hücrelerin çoğunun aksine, TERT transkripsiyon aktivitesinin upregüle olduğu gösterilmiştir (14,15). Elkak ve ark. (16) meme kanser hastalarında hTERT genin ekspresyonunu sağlıklı örneklere kıyasla yüksek olduğunu, fakat istatiksel olarak anlamlı bir fark bulamadıklarını rapor etmişlerdir. Aynı şekilde Kirkpatrick ve Mokbel (2001) de hTERT genin ekspresyonunu meme kanser örneklerinde yüksek bulmuşlardır (17). Benzer sonuçları bulan 2017 yılında yapılmış bir diğer çalışmada ise Can ve ark. (18) tümör örneklerinde hTERT genin ekspresyonunu sağlıklı örneklere kıyasla yüksek olduğunu rapor etmişlerdir. Bizde bu çalışmamızda literatürle benzer ve uyumlu bir şekilde hTERT genin ekspresyonunu meme kanser örneklerinde sağlıklı örneklere kıyasla yüksek olduğunu gösterdik.

Düşük hTERT geni ekspresyon durumunun müsinoz karsinomalarda, duktal ve lobüler karsinomalara kıyasla iyi prognoz ilişkili olduğu gösterilmiştir (16). Bir başka çalışmanın sonuçlarına göre, meme kanser örneklerinde hTERT genin hastaların yaşı, tümör boyu, grade, nod ve ER durumu ile herhangi bir anlamlı ilişski bulamadıklarını bildirmişlerdir (17). Hines ve ark. (2005) yüksek gradeli meme tümörlerinde hTERT geni ekspresyon seviyesinin normalin üzerinde olduğunu bildirmişlerdir (19). Bizde bu çalışmamızda hTERT geni ekspresyonunu ER(+) ve HER2 (+) olan meme kanser örneklerinde istatiksel olarak anlamlı ve düşük ekspresyon profiline sahip olduklarını gösterdik. hTERT geni ekspresyonu histolojik derece 3'e sahip olan hastalarda histolojik derece 2'ye sahip olan hastalara kıyasla anlamlı ve yüksek olduğunu gösterdik. Bununla birlikte son olarak hTERT geni ekspresyon seviyesinin bazal benzeri moleküler tipe sahip hastalarda luminal A ve luminal B'ye sahip olan hastalara kıyasla anlamlı derecede yüksek olduğunu belirledik.

Literatüre baktığımızda meme kanserinde hTERT geni ekspresyonununu baskılamayı hedefleyen bazı denemeler (araştırmalar) da yapılmıştır. Bunlar arasında bir ilaç salım çalışmasında, T47D meme hücre hattında hTERT ekspresyon seviyesi üzerindeki bireysel ve kombine ilaçların sitotoksik ve inhibe edici etkileri araştırıldığında, metformin (Met), curcumin (Cur) ve Met-Cur kombinasyonunun serbest ve nano kapsüllenmiş formlarda hTERT geni ekspresyonunu inhibe ettiğini göstermişlerdir (20). Bir başka araştırmada ise, çinko parmak E-kutusu bağlayıcı homeobox 1 (Zinc finger Ebox binding homeobox 1) (ZEB1)'in büyümeyi uyardığ ve meme kanserinde invazif duktal karsinoma örneklerinde hem mRNA hem de protein seviyelerinde hTERT ekspresyonu ile pozitif bir ilişkisi olduğu bildirilmiştir. $\mathrm{Bu}$ araştırmada aynı zamanda meme kanserinde hücre proliferasyonunun düzenlenmesinde rol oynayan yeni bir ZEB1-hTERT sinyal yolu ortaya çıkarılmıştır (21). Noureini ve ark. (2018) ise chelidonine kullanarak MCF7 hücre hattında telomer uzunluğunu büyük ölçüde azalttıklarını göstermişlerdir. (22). Zhang ve ark. (2020) RIN1'in (Ras and Rab interactor 1) aşırı eksprese olduğu zaman, telomeraz aktivitesini ve hTERT ekspresyonunu bloke ettiğini göstermişlerdir (23). Mathiyazhagan ve Muthukaliannan (2020) MCF7 hücre hatlarına Zingiber officinale ( $\mathrm{ZO})$ ve Terminalia chebula (TC) maddelerini uygulayarak, hücre proliferasyonunda rol oynayan mTOR ve hTERT genlerinin ekspresyon seviyesini aşağı yönde etkilediklerini bildirmişlerdir(24). Diğer bir çalışmada ise, hTERT aşağı regülasyonunun, meme kanseri hücrelerinin doksorubisine duyarlılığının artmasına yol açtığını rapor edilmiştir (25). 


\section{SONUÇ}

Sonuçlarımıza göre, Türk popülasyonunda meme kanser hastlarında hTERT geni ekspresyon seviyesinin sağlıklı bireylere kıyasla yüksek olduğu ve bundan dolayı meme kanser hastalarımızın telomeraz aktivitesinin de bu durumdan etkilenmiş olabileceğini göstermektedir. Ayrıca yüksek histolojik dereceli örneklerde de ekspresyon seviyesinin yüksek olduğu belirlendi. Bütün bu bulgularımız gelecekte daha geniş meme kanser hasta popülasyonlarında yapılacak araştırmalar sayesinde, hTERT genin ekspresyon seviyesi profiline göre meme kanser patolojisinin tahmin edilebileceğini düşünüyoruz. Aynı zamanda bu genin prognoztik veya prediktif öneminin açığa çıkarılması ve hedefe yönelik yeni tedavi modellerinin keşfedilmesine 1şık tutacağına inanıyoruz.

Çıkar çakışması beyanı

Yazarlar bu yazının hazırlanması ve yayınlanması aşamasında herhangi bir çıkar çakışması olmadığını beyan etmişlerdir.

Finansman

Yazarlar bu yazının araştırma ve yazarlık sürecinde herhangi bir finansal destek almadıklarını beyan etmişlerdir.

Yazarların Katkıları: Fikir/Kavram: E.D., B.K., Z.T; Tasarım: E.D.; Veri Toplama ve/veya İşleme: E.D., B.K., Z.T; Analiz ve/veya Yorum: E.D., B.K, Z.T..; Literatür Taraması: E.D. B.K.; Makale Yazımı: E.D., B.K; Eleştirel İnceleme: E.D., B.K, Z.T.

\section{KAYNAKLAR}

1. Zhang J, Tian Q, Zhang M, Wang H, Wu L, Yang J. Immune-related biomarkers in triple-negative breast cancer. Breast Cancer [Internet]. 2021 Apr 9; Available

from: https://link.springer.com/10.1007/s12282-021-012478

2. Elsers D, Temerik DF, Attia AM, Hadia A, Hussien MT. Prognostic role of ALK-1 and h-TERT expression in glioblastoma multiforme: correlation with ALK gene alterations. J Pathol Transl Med [Internet]. 2021 May 11; Available from: http://www.ncbi.nlm.nih.gov/pubmed/33966367

3. Bieche I, Nogues C, Paradis V, Olivi M, Bedossa P, Lidereau R, et al. Quantitation of hTERT gene expression in sporadic breast tumors with a real-time reverse transcription-polymerase chain reaction assay. Clin Cancer Res. 2000; 6(2): 452-9.

4. Zhang J, Tian Q, Zhang M, Wang H, Wu L, Yang J. Immune-related biomarkers in triple-negative breast cancer. 1994; 266(5193): 2011-5.

5. Buseman CM, Wright WE, Shay JW. Is telomerase a viable target in cancer? Mutat Res. 2012; 730(1-2): 90-7.

6. Wright WE, Piatyszek MA, Rainey WE, Byrd W, Shay JW. Telomerase activity in human germline and embryonic tissues and cells. Dev Genet. 1996; 18(2): 173-9.

7. Low KC, Tergaonkar V. Telomerase: central regulator of all of the hallmarks of cancer. Trends Biochem Sci. 2013; 38(9): 426-34.
8. Wang K, Wang R-L, Liu J-J, Zhou J, Li X, Hu W-W, et al. The prognostic significance of hTERT overexpression in cancers: A systematic review and meta-analysis. Medicine (Baltimore). 2018; 97(35): e11794.

9. Kirkpatrick KL, Mokbel K. The significance of human telomerase reverse transcriptase (hTERT) in cancer. Eur J Surg Oncol. 2001; 27(8): 754-60.

10. Yoon AJ, Santella RM, Wang S, Kutler DI, Carvajal RD, Philipone E, et al. MicroRNA-based cancer mortality risk scoring system and htert expression in early-stage oral squamous cell carcinoma. J Oncol. 2021; 2021: 8292453.

11. Castiglia P, Sanna V, Azara A, De Miglio MR, Murgia L, Pira G, et al. Methylenetetrahydrofolate reductase (MTHFR) C677T and A1298C polymorphisms in breast cancer: a Sardinian preliminary case-control study. Int J Med Sci. 2019; 16(8): 1089-95.

12. Bagheri R, Sanaat Z, Zarghami N. Synergistic Effect of Free and Nano-encapsulated Chrysin-Curcumin on Inhibition of hTERT Gene Expression in SW480 Colorectal Cancer Cell Line. Drug Res (Stuttg). 2018; 68(06): 335-43.

13. Jafri MA, Ansari SA, Alqahtani MH, Shay JW. Roles of telomeres and telomerase in cancer, and advances in telomerase-targeted therapies. Genome Med. 2016;8(1):69. A

14. Wright WE, Piatyszek MA, Rainey WE, Byrd W, Shay JW. Telomerase activity in human germline and embryonic tissues and cells. Dev Genet. 1996; 18(2): 173-9.

15. Takakura M, Kyo S, Kanaya T, Hirano H, Takeda J, Yutsudo $\mathrm{M}$, et al. Cloning of human telomerase catalytic subunit (hTERT) gene promoter and identification of proximal core promoter sequences essential for transcriptional activation in immortalized and cancer cells. Cancer Res. 1999; 59(3): 551-7.

16. Elkak A, Mokbel R, Wilson C, Jiang WG, Newbold RF, Mokbel K. hTERT mRNA expression is associated with a poor clinical outcome in human breast cancer. Anticancer Res. 2006; 26(6C): 4901-4.

17. Kirkpatrick KL, Mokbel K. The significance of human telomerase reverse transcriptase (hTERT) in cancer. Eur J Surg Oncol. 2001; 27(8): 754-60.

18. Çalışkan Can E, Atalay MC, Miser Salihoğlu E, Yalçıntaş Arslan Ü, Şimşek HB, Yardım Akaydın S. Normal and tumour tissue mRNA expressions of telomerase complex genes in several types of cancer. Balkan Med J. 2017; 34(3): 269-74.

19. Hines WC, Fajardo AM, Joste NE, Bisoffi M, Griffith JK. Quantitative and spatial measurements of telomerase reverse transcriptase expression within normal and malignant human breast tissues. Mol Cancer Res. 2005; 3(9): 503-9.

20. Farajzadeh R, Pilehvar-Soltanahmadi Y, Dadashpour M, Javidfar S, Lotfi-Attari J, Sadeghzadeh H, et al. Nano-encapsulated metformin-curcumin in PLGA/PEG inhibits synergistically growth and hTERT gene expression in human breast cancer cells. Artif cells, nanomedicine, Biotechnol. 2018; 46(5): 917-25. 
21. Yu P, Shen X, Yang W, Zhang Y, Liu C, Huang T. ZEB1 stimulates breast cancer growth by upregulating hTERT expression. Biochem Biophys Res Commun. 2018; 495(4): 2505-11.

22. Kazemi Noureini S, Fatemi L, Wink M. Telomere shortening in breast cancer cells (MCF7) under treatment with low doses of the benzylisoquinoline alkaloid chelidonine. Lustig AJ, editor. PLoS One. 2018; 13(10): e0204901.

23. Zhang W, Veisaga ML, Barbieri MA. Role of RIN1 on telomerase activity driven by EGF-Ras mediated signaling in breast cancer. Exp Cell Res. 2020; 396(2): 112318.

24. Mathiyazhagan J, Kodiveri Muthukaliannan G. Combined Zingiber officinale and Terminalia chebula Induces Apoptosis and Modulates mTOR and hTERT Gene Expressions in MCF-7 Cell Line. Nutr Cancer. 2020; 1-10.

25. Romaniuk-Drapała A, Totoń E, Konieczna N, Machnik M, Barczak W, Kowal D, et al. hTERT downregulation attenuates resistance to DOX, impairs FAK-mediated adhesion, and leads to autophagy induction in breast cancer cells. Cells. 2021; 10(4): 867. 